\title{
ARCFELISMERÉS: \\ A VONZÁS-ELUTASÍTÁS LEHETSÉGES VONÁSAI SZONDI-KÉPEKEN
}

\section{RÉVÉSZ GYÖRGY-JÁRAI RÓBERT}

Pécsi Tudományegyetem, Bölcsészettudományi Kar,

Általános- és Evolúciós Pszichológiai Tanszék

E-mail: revesz@btk.jpte.hu, kurgy@btk.jpte.hu

\begin{abstract}
„Ha a másik arca sokkal több testi vágyat kelt benned, mint teste bármely más része, akkor biztosan tudod, hogy szereted öt."
\end{abstract}

Michel Tournier

Az emberi arc fizikai megjelenésének vizsgálata - az arc jellemzö vonásainak és a pszichológiai karakter/személyiség-onások lehetséges összefüggéseinek feltárása - az antropológiában, néprajzban, irodalmi karakterek megformálásában, valamint a pszichológia tudomány elötti idöszakától napjainkig az érdeklödés fókuszában áll. A fiziognómiai kutatások eredményei azonban jórészt az arcvonásokra, arcvonásmintázatokra épülö attribúcióknak bizonyultak, míg azok a vizsgálatok, amelyek fényképekröl arcvonások és személyiségvonások összefüggéseit kívánták feltárni, statisztikailag bizonytalanok.

A fizikai vonzerö kutatásaiban újabban etológiai, szociobiológiai vizsgálatok sora tárt fel eredményeket az arc átlagos megjelenése, szimmetriája és a vonzerö összefüggéseiröl.

A Szondi-teszt képeinek vizsgálatáról igen kevés adat áll rendelkezésünkre. A képek vizuális jellemzöninek (megzilágítás, kontraszt, élesség, részletesség, raszter, mimika stb.) a választásokra gyakorolt hatásairól csak tendenciaszerü összefüggést találtak. Szondi a képek választásában az ösztönszükséglet - a tárgyak lewini felszólitó jellegének megfelelö- dinamikáját tartotta a legfontosabb tényezönek.

Vizsgálatunkban a Szondi-képek metrikus adatainak arányszámaiban több tendenciaszerü különbséget, az aranymetszés szabálya szerint jelentös különbséget találtunk az átlagprofil szimpatikus/antipatikus csoportja között.

Kulcsszavak: $\quad$ arcfelismerési modellek, vonásdetekció vs. templátillesztés; arc és karakter; átlagosság, szimmetria és vonzerö́; az arc „,arányossága” 
Az emberi arc sokkal több információt jelent számunkra, mint a test bármely egyéb része. Különleges biológiai szerepével (a legfontosabb érzékszervek az arcon helyezkednek el) az arc döntő szerepet tölt be a mindennapi életben. Az evolúció eredményeként az arc és az arckifejezés a főemlősöktől kezdődően helyettesíti a szaginformáción alapuló kommunikációt. Az arc gazdag információforrás a személy azonosításában, felismerésében, az érzések és hangulatok észlelésében, a társas érintkezésben, a társalgásban (például a tekintet), továbbá a nem, az életkor, a foglalkozás, a különböző sztereotípiáknak megfelelő attribúciók tekintetében is. DARWIN (1892/1963, 254) az érzelmekről írt művében hangsúlyozza: „Testünk valamennyi része közül az arcot figyeljük és nézzük a legtöbbet, ami különben természetes, mert ez a kifejezés legfontosabb székhelye és a hang forrása. A szépségnek és a rútságnak is ez a legfontosabb helye, és szerte az egész Földön, a test legtöbbet ékesített része".

Bár minden emberi arc hasonló vonásokkal bír és alapvetően hasonlít egy másik arcra, még sincs két tökéletesen egyforma arc a világon. Ezt figyelte meg GALTON (1883), amikor összegzett, „átlag” arcfényképeket készítve rámutatott, hogy az arc olyan vizuális kategória, amely hasonló régiókat tartalmaz (szem, orr, száj stb.), s ezek általános elrendeződése azonos (lásd 1. ábra).

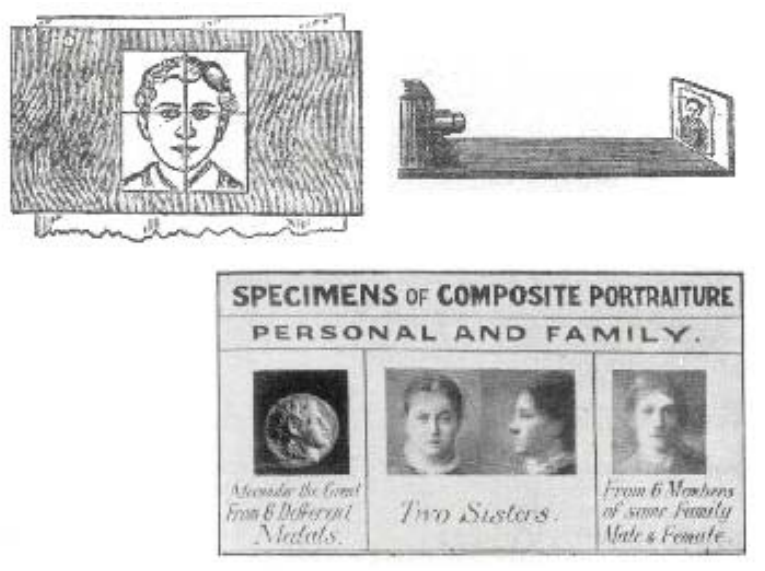

1. ábra. Galton berendezésének vázlata és egy összegzett arc (In BRUCE, YOUNG, 1998, 126.)

Galton azt is tapasztalta, hogy az így előállított átlagos arc vonzóbb a megfigyelők számára, mint az egyedi.

$\mathrm{Az}$ arcfelismeréshez ennek az alapkonfigurációnak a megkülönböztetése szükséges, ennek ellenére képesek vagyunk ismerős arcok gyors azonosítására akár több millió ismeretlen arc közül is. Arcok azonosítása több dimenzió mellett történik, például „,ismerősség”, nem, rassz, életkor stb., jellemző vonások (features) segítségével. Az emberi arc kitüntetett szerepét igazolja, hogy könnyebben ismerhetőek fel, mint más vizuális ingerek: abban az értelemben „speciális” inger, hogy hasonló és ismert ingerosztályt képvisel. 


\section{ARCFELISMERÉSI MODELLEK}

Az arcfelismerés sajátos jellegét támasztja alá YIN 1969-es vizsgálata, amelyben a fejjel lefelé bemutatott arcok azonosítása komplexebb és sokkal nehezebb volt a kísérleti személyek számára - még akkor is, ha igen jól ismert személyek fényképeit mutatták be - mint megfordított tárgyak felismerése. Egyik ilyen kísérletben a jól ismert személyeket 71\%-ban azonosították normál helyzetben, és csak 12\%-ban ismerték fel a megfordított arcokat. Az arcfelismerés kognitív pszichológiai modellezésében és vizsgálatában több megközelítés ismeretes. A holisztikus modell mellett ismert a vonás alapú modell, amely különbséget tesz az egymástól jól elkülöníthető, izolált elsőrendű vonások (például orr, szemek) és a másodrendű vonások között, amely tartalmazza az elsőrendű vonások téri viszonyait és az arc kontúrján belüli lokalizációját. Ezek között a tárgyfelismerés modelljeként jól ismert geometriai vonások vektora(i) vs. templát illesztés vitája lehet jelentős, mert mindkét megközelítés mellett számos megfigyelés eredményei szolgáltatnak adatokat. RHODES (1988) szerint az egyenes állású arcok felismerése holisztikus, míg a fordított állásúaké a részletek felől halad. Más vizsgálatok szerint arcok azonosításában a „kis templátok” (például: szem, száj, orr) hasonló szerepet töltenek be, mint az önálló, egyedi vonások. A vita egyik lehetséges feloldása tehát: az első kritikus lépés a szem detekciója $\rightarrow$ illesztés a szem „prototípussal”, majd a szem-szemöldök templáttal, s ehhez hasonlóan a többi szignifikáns rész (orr, száj) vonás alapú detekciója felöl egyre összetettebb mintaillesztési folyamatok zajlanak le (BRUNELLI, POGGIO, 1993, lásd 2. ábra).

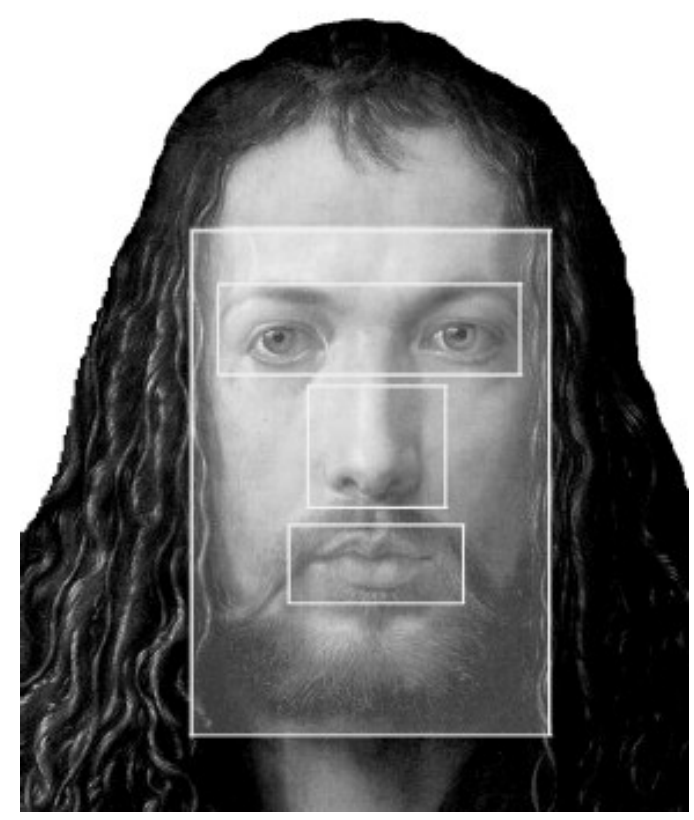

2. ábra. Különböző régiók a templát illesztési stratégiában (Bodó László jóvoltából) 
A résztemplátok téri elhelyezkedése (például a szemek távolsága, az orr hossza, szélessége, szájtól való távolsága stb.) az egyszerü azonosításon (ismerős-nem ismerős) túl igen fontos szerepet töltenek/tölthetnek be az érzelmi állapotok azonosításán át a rokonszenv-ellenszenv döntésekben is. Amikor megfigyelünk és leírunk egy arcot, nagyobb figyelmet fordítunk az arc felső régiójára (haj, szemek), mint az alsó részre (száj, áll) (HAIG, 1986). Az archasonlóság ítéleteinél nagyobb figyelmet szentelünk az arc alakjának, a haj megfigyelésének és az életkor jelzéseinek, mint más részleteknek (SHEPHERD, 1981). Az arcfelismerés két (vagy több) egymásra épülő folyamatát leírják úgy is, mint fizikai/strukturális és szemantikus szint (KLATSKY, MARTIN, KANE 1982) vagy a feldolgozás magasabb szintjein „epizodikus ítélet” és „diszpozicionális impresszió” (KNAPPER, idézi ALLEY, 1988). A szemantikus szint nem csak elméleti probléma: balesetek, bünügyek szemtanúit gyakran kérik arra, hogy a Identikit vagy a Photo fit fényképkészletéből állítsák össze a látott személy arcképét. Laboratóriumi vizsgálatok szerint a hasonlóság mértéke igen alacsony, s ez nem csupán abból fakad, hogy a készlet elemei korlátozott számúak vagy hogy az összeállítás „önkényes” (SHEPHERD, ELLIS, 1996). Egy korábbi vizsgálatában SHEPHERD (1981) kétféle leírással (többszörös gyilkos vs. hajóskapitány, akit a közelmúltban tüntettek ki bátorságáért) mutatott be egy arcképet a kísérletben részt vevő személyeknek. Valamivel később megkérte őket, hogy az osgoodi SD skálán jelöljék le a korábban látott képet. A két csoport eredményei a kilenc skálából nyolcban különböztek egymástól. Ezt követte a Photo fit készletéből az arc összeállítása. Ezután független személyekkel jelöltette le hasonló skálán a kapott képeket: a „hajóskapitány” képét szignifikánsan vonzóbbnak ítélték, mint a "gyilkosét”. A ma legismertebb megközelítés - Bruce és Young (EYSENCK, KEANE, 1997) információfeldolgozási modellje - szerint egy adott ingerosztály feldolgozására többé-kevésbé független rendszer vagy modul szolgál. Az azonosítási folyamat párhuzamosan megy végbe az érzelmi kifejezés elemzéssel és a szájról olvasással. Az azonosítás összetevője az észlelési osztályozás („,arcfelismerési egységek”), a jelentéselemzés („,a személyazonosság nóduszok”) és a név külön tárból való előhívása. Az arcfelismerési egységek biztosítják az ismert arc új nézetéről az ismerősséget, s tartalmazzák az ismert arcok strukturális információit, néző központú reprezentációit. A személyazonosság nóduszok gondoskodnak a személyre vonatkozó különböző információkhoz (például foglalkozás, érdeklődés, hang, barátok, ahol elő szokott fordulni stb.) való hozzáférésről. A modell további eleme az „irányított vizuális feldolgozás”, amely adott arcinformációk meghatározott célú feldolgozását szolgálja. A „kognitív rendszer” további információkat tartalmaz (például a színésznők általában vonzóak), amelyeket néha felhasználunk az arc azonosításában. A modell lényeges eleme a strukturális kódolás, amely nagyjából MARR (1982; magyarul összefoglalja KOVÁCS, 1991) komputációs elméletének megfelelően reprezentációkat vagy leírásokat eredményez. Sokat vizsgálták a téri frekvenciák szerepét az arcfelismerésben, s feltételezték egyfajta téri frekvencia kitüntetett szerepét (arcképek különböző frekvenciájú szűrőkkel történő átalakítása és a felismerés összefüggéseinek vizsgálata elterjedt módszer, lásd például CosTen és munkatársai, 1994, 1996).

Bruce és Young egyik elméleti érve, hogy ismert és ismeretlen arcok feldolgo- 
zása eltérő. Így ismeretlen arcok esetében nyilvánvalóan nem működnek a modell bizonyos összetevői (például arcfelismerési egységek, névelőhívás). A feltevés jogosságát igazolja az, hogy találtak olyan agysérültet, aki fel tudta ismerni fényképről a híres embereket, de károsodott teljesítményt nyújtott ismeretlen arcokat összehasonlító feladatban, míg egy másik beteg teljesítménye ennek éppen ellenkezője volt: normál szinten maradt az ismeretlen arcok összehasonlítása, de sérült a híres emberek felismerése. A prosopagnosiás beteg esetében is szétválik az ismerős és az ismeretlen arc feldolgozása, ami újfent az eltérő feldolgozást támasztja alá. A párhuzamos feldolgozás mellett felhozható érv az arcfelismerés és arckifejezés feldolgozásának elkülönülése egyes prosopagnosiás betegeknél. Egyes betegeknél mind az érzelem, mind a személy felismerése sérül, másoknál sértetlen marad az érzelmi megkülönböztetés és elvész az arcfelismerés, de ez fordítva is igaz lehet (Tranel és munkatársai, 1988). Az arcfelismerésben tehát különböző feldolgozási folyamatok vesznek részt, és különbségek vannak az ismerős és az ismeretlen arc feldolgozásában. Az arcfelismerés specializált feldolgozási rendszerben, „modulban” megy végbe, amely sok tekintetben hasonló a tárgyfelismerésben érintett egyéb rendszerhez vagy rendszerekhez (modulokhoz). Az összetett folyamat részleteinek feltárása azonban még várat magára (MOSCOVITCH, WiNOCUR, 1997).

A felismerés különböző szintű múködését igazolják a modern képalkotó eljárások (fMRI, PET), valamint az ERP vizsgálatok eredményei is, amelyek az arc és a tárgyfelismerés részben eltérő idegi mechanizmusairól tudósítanak (ALLISON és munkatársai, 1994). Így például megfigyelték, hogy néhány ERP hullámforma amplitúdója nagyobb, latenciaideje rövidebb arcok esetében, mint tárgyfelismerési feladatban.

Elektrofiziológiai és a funkcionális képalkotó eljárások vizsgálati eredményei szerint három neurális rendszer kap eltérô szerepet az arcfelismerésben:

1. jobb temporo-occipitális sulcus, amely az arcvonásokra, különösen a szemre érzékeny;

2. jobb laterális fusiform gyrus, amely a konfigurációra ad szelektív választ (másodrendű vonások);

3. jobb oldali fusiform gyrus anterior területe és a parahyppokampális gyrus, melyek az arcazonosítás szemantikai/fiziognómiai aspektusaira érzékenyek, míg a bal oldali hasonló területek a megnevezésben kapnak szerepet.

\section{EMBERI ARC ÉS KARAKTER}

Az emberi arcvonások és a karakter vagy más pszichológiai tulajdonságok összefüggéseinek feltárása Arisztotelész Physiognomicájáig vezethető vissza, s bár azóta számos munka igazolta ezek tudományos megalapozatlanságát azzal, hogy a fiziognómiai ítéletek a sztereotípiák világába tartoznak, a szociális interakciókban mégis potenciális predikciók forrásai. Míg az arc fiziognómiai vizsgálatainak jó része az összbenyomás különböző skálákon történő jelölését végezte el, az arc egyes 
régióinak egymáshoz való viszonyát vizsgálva Brunswik és Reiter (BRUNSWIK, 1956) kísérletükben egyszerü, sematikus arcokat készítettek (lásd 2. ábra). A kipróbálás során kiderült, hogy a haj hozzáadása hasonlóvá teszi az arcokat, más tulajdonságok elhagyása, mint például a pupilláké pedig valószerütlenné teszi azt. A „kompromisszumos” arcot végül úgy szerkesztették, hogy ovális kontúrja, egyenes száj- és orrvonala legyen, a szemek pedig ellipszis alakúak (lásd 3. ábra).

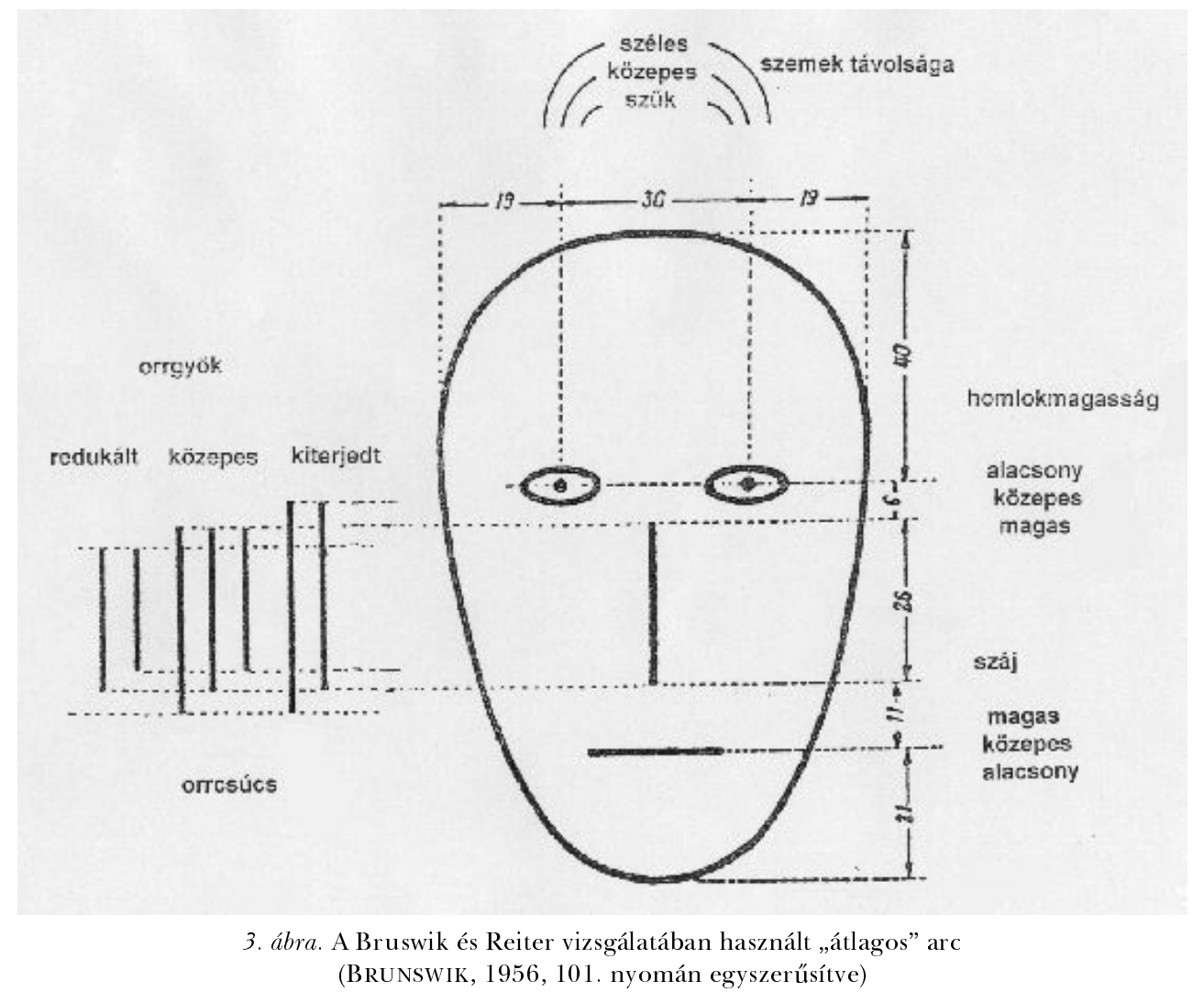

További vizsgálataikban az arc következő aspektusait változtatták szisztematikusan: az orr hossza, homlokmagasság (a szemek horizontális pozíciója), a szájak magassága, a szemek távolsága (a teljes sorozat vizsgálatakor néhány kombinációt túl valószerütlennek vagy groteszknek találtak, ezért ezeket kihagyták). A végső változatban a sorozat 189 sematikus arcból állt. Ezután lejegyezték a kísérleti személyek arcleírásait, és ezt vették alapul a végső leíró skálák megalkotásához: vidám-szomorú, fiatal-öreg, jó-rossz, valóságos-valószerütlen, csúnya-szép, intelligens-primitív, energikus-erőtlen. Utólag a sorozatot 7 fokú skálán értékeltették. Végül az arányszámokat a 0-pontba transzformálták, 0-100 pont közé (a 0 a legkevésbé kedvelt, 100 a legkedveltebb). Kísérleti eredményeik szerint a szemek 
távolsága, a homlok magassága, a száj magassága, az orrforma (szélesség/hosszúság változói) és a hangulati állapot, életkor, jó-rossz karakter, szépség, intelligencia, változók között energiaváltozók találtak együttjárásokat. A pszichológiai tulajdonságok (vonások) között együttjárás vagy csoportosíthatóság lehetséges:

a) látszólagos hangulat és kor,

b) karakter, valószerüség és szépség,

c) intelligencia és energikusság között.

A száj magasságának változtatása a legextrémebb választ eredményezte: minél magasabban van a száj, annál vidámabb és fiatalabb az arc a kísérleti személyek ítéletei szerint (és fordítva), viszont az alacsony száj intelligenciát tükröz. A távol ülő szemek és a rövid orr ugyanolyan hatást kelt, mint a magas száj. A hosszú orr kedvezőtlen benyomást kelt. A magas homlok általában kedvezőbb ítéleteket kapott. Ezt követően elvégzett VA szerint az összes hatás szignifikáns volt, az arcészlelés jelzőingerei fontossági sorrendben pedig az alábbiak:

1. homlokmagasság,

2. szájmagasság, szemek távolsága.

Brunswik és Reiter eredményei szerint tehát azok a „súlyos” benyomások, melyeket nap mint nap másokról alkotunk, igen egyszerű mintázatok alapján keletkeznek. Tapasztalataik szerint kis változások ezekben a mintázatokban megváltoztatták az általuk indukált benyomásokat is, az arc valóban szomorúbbnak, fenyegetőbbnek tünik. Ez azt mutatja, hogy viszonylag kevés információ szükséges az arcszerűség benyomásának elérésére. Később GORDON (1989) és munkatársai megismételték a Brunswik-Reiter képek vizsgálatát angol, afrikai és kínai gyermekekkel és igen hasonló válaszokat kaptak, vagyis az adott sztereotíp válaszok univerzálisak.

Az emberi arc és a karakter (személyiségvonások) lehetséges összefüggéseit feltáró 1974-es Liggett-vizsgálatban (ALLEY, 1988) egyetemi hallgatók többsége úgy vélte, hogy az arc (különösen a száj) fontos támpont a személyiség és a szociális osztály kategorizálásában (mindössze 10\%-a gondolta, hogy az arc nem fontos a karakter megismerésében). Egy másik vizsgálatban - Mazur, Mazur, Keating, 1984 (ALLEY, 1988) szignifikáns korrelációt találtak a kadétok fényképein észlelt dominancia és a katonai elómenetel között a West Point Katonai Akadémián. Nem véletlen, hogy a fénykép a mai napig szinte elengedhetetlen része az állásokra való jelentkezésnek vagy házassági hirdetéseknek. Ezért a fényképek megítélésében a kultúra által szabályozott szociális funkciót feltételeznek.

Az emberi arc kiterjedt attribúciók forrása. Secord szerint (SHEPHERD, 1989) az arc gyors válaszok forrása: 1 . az emberek közötti szociális osztálybeli, nemi és rasszbeli hovatartozásának megítélésében; 2. érzelmi (hangulati) állapotok felismerésében (így például a mosolygó arc a ,jókedv" hangulati állapoton túl erre utaló személyiségvonásra vonatkozó ítéletek forrása lehet); 3. etológiai elméleteken alapuló megfigyelések az arcattribútumok és a dominancia, függőség szignáljai lehetnek.

Az emberi arc legkönnyebben megkülönböztethető vonásai a nemek eltérő arcfelépítéséből fakadnak: a férfiak nagyobb orra, kifejezettebb szemöldöke, „mélyebben ülő szemei”, szemben a nők kisebb orra, kevésbé erőteljes szemöldöke, az 
arcszőrzet hiánya stb. - feltűnő azonosítási jegyek. E jegyek gyengébb vagy éppen erőteljesebb formái szerepet kapnak az adott nemhez kötött, „férfias” vagy „nőies” viselkedés attribúciójában is. Egy vizsgálatban Keating (idézi SHEPHERD, 1989) az Identikit fényképsorozatával a szemöldök szögét és vastagságát, a szem nagyságát, az ajkak vastagságát, valamint az áll méretének hatásait vizsgálta a dominancia ítéleteire. Eredményei szerint a kis szemek és az ajak vékonysága asszociálódik a dominancia ítéleteivel. Egy további vizsgálat (SHEPHERD, 1989) szerint az áll nagysága az arrogancia ítéleteivel korrelál...

\section{AZ ARC VONZEREJE}

Az emberi test - ezen belül az arc - szépsége, vonzereje, az arc egyes régióinak, egymáshoz való viszonyának, geometriai arányainak ismerete a görög szobrászatban megjelenik (,... a müalkotás legelső és legfontosabb célja a szépség...” DARWIN, 1892/1963, 18). Az „ideális” (ezért vonzó) arc legkorábban ismert aránya az aranymetszés szabályszerüségét mutatja, amely szerint az egész arc $(x)$ úgy aránylik az áll-szem távolsághoz (y), mint az áll-szem távolság (y) a homlok (z) nagyságához; továbbá hét egyenlő részre osztható (lásd 4. ábra).

A festészetben később Leonardo da Vinci és Dürer képein úgy jelenik meg az ideális arc, mint amely 1 . szimmetrikus; 2. a szemek távolsága egyenlô egy szem vagy az orr szélességével; 3. az orrhegy éppen felezi az áll-szemöldök távolságot.

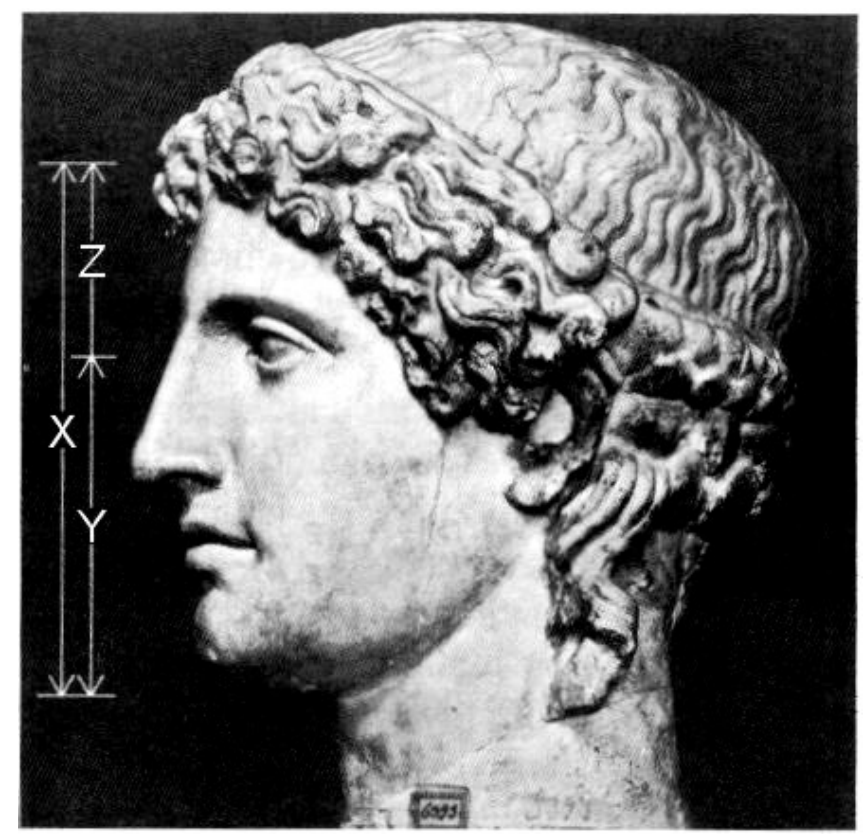

4a ábra. Az aranymetszés szabálya Apolló szobrán 


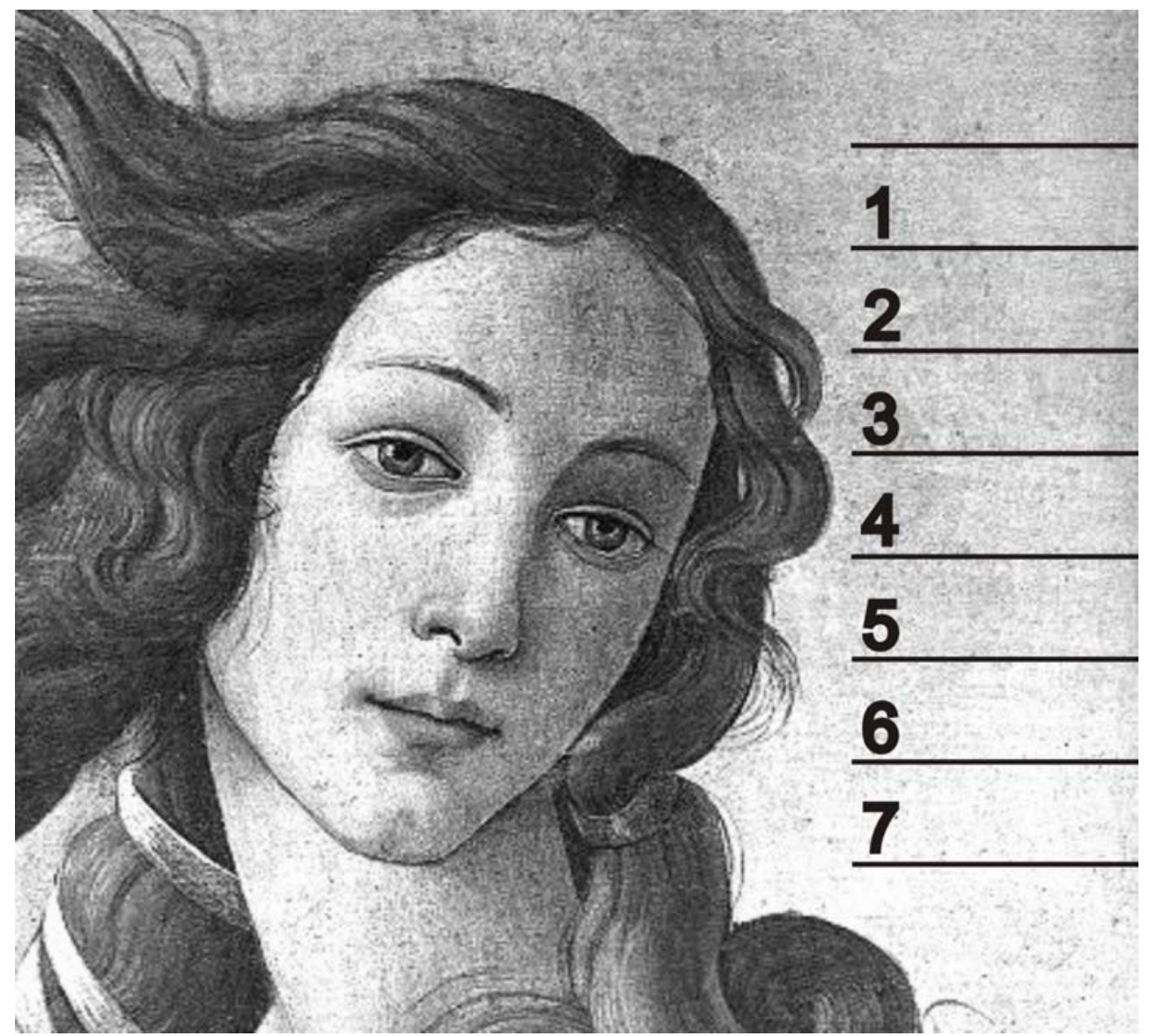

4/b ábra. Botticelli: Vénusz születése címü képén Vénusz arca hét egyenlö részre osztható

Az arc vonzereje univerzális: az attraktivitás ítéletei magas kultúrközi egyezést mutatnak (például CunNingHAM és munkatársai, 1995; vö. Brunswik-Reiter, illetve Gordon vizsgálataival). Ebben inkább biológiai evidenciákat vélnek okként feltételezni, mint kulturális hatásokat: 2 hónapos csecsemők jobban preferálják két kép közül a vonzóbb arcot, állapítják meg LANGLOIS és munkatársai (1991), míg SLATER és munkatársai (1991) igazolták, hogy már újszülöttek is preferálják a vonzó arcot.

Az arc átlagos megjelenési formája és a vonzerő, illetve ennek a párválasztásban betöltött szerepe kitüntetett vizsgálati terepe az evolúciós pszichológiának is (Bereczkei, 1999; Penton-VOAK, Perrett, 2000). E vizsgálatok a galtoni eredményekig nyúlnak vissza, amelyben - mint ezt korábban említettük - a mesterségesen előállított átlagos arc vonzereje nagyobb, mint az átlagosé, az igazán vonzó arc azonban már nem átlagos (ALLEY, CUNNINGHAM, 1991; vö. az arc szimmetriá- 
ja és a vonzerő kapcsolata)! A modern PC-technikával előállított képek vizsgálatai jórészt alátámasztották Galton eredményeit (BERECZKEI, 1999). Az „átlagos” arc az evolúciós pszichológusok felfogásában a tulajdonos heterozigóta jellegét mutatja, szemben az extrém (itt nem átlagos) arcformával, annak kisebb adaptív jellegével. LANGLOIS és ROGGMAN (1990) véleménye szerint az „átlagos” preferenciája kézenfekvő módon vethető egybe a kognitív pszichológia „prototípus” fogalmával éppúgy, mint a genetikában ismert „visszacsapás az átlaghoz” néven közismert jelenségével.

Az arc szimmetriája a vonzerô további, az előbb tárgyalt átlagos arcberendezkedéstől független(!) forrása. Az alapvetés szerint a szimmetria magasabb foka nagyobb vonzerővel jár. A szimmetria növelését célzó PC-alapú eljárások azonban sajátos eredménnyel jártak: ha a konstruált arc egy reális arc egyik oldalának tükörképe („kimérikus” arc), természetellenes vonások jelennek meg (mivel az emberi arc geometriai pontossággal sosem tükörszimmetrikus, például a száj egyik oldalon hosszabb, így a kimérikus arcon túl kicsi vagy éppen aránytalanul nagy a száj). Az így konstruált arc kétségkívül szimmetrikus, vonzereje azonban kisebb, mint a kiinduló arcé volt (PENTON-VOAK, PERRETT, 2000). Ha azonban a kísérleti arcot nem átlagos arcokból, hanem a korábban már vonzónak ítélt arcokból állították elö, ez növelte a vonzerő mértékét, mi több, az így létrehozott ún. „szuper” arc kapta a legnagyobb vonzeró-pontszámokat (BERECZKEI, 1999). LANGLOIS, ROGGMAN és MusSELMAN (1994) viszont nem találtak szignifikáns korrelációt a szimmetria mértéke és a vonzerő között; SWADDLE és CUTHILL (1995) a „nagyon” szimmetrikus arcok esetében a vonzerő csökkenését tapasztalták. KowNER (1996) eredményei szerint - semleges arckifejezés esetén - a szimmetria csak idős emberek képein járt együtt a vonzerő magasabb fokával. Ha az ingeranyag mosolygó arc, akkor az aszimmetrikus vonzóbb, mint a szimmetrikus. Végül a szimmetria és a vonzerő összefüggéseinek nemi különbségeiről szóló egyik beszámoló (GRAMMER, THORNHILL, 1994) szerint a mesterségesen szimmetrikussá tett női arcok vonzóbbak voltak, mint az eredeti arcok, férfiaknál fordítva: az eredeti férfi arcok magasabb pontértéket kaptak a vonzerőskálán, mint a szimmetrikussá tett arcok.

\section{A SZONDI-TESZT KÉPEI}

Mint ismeretes, a teszt képanyagában pszichiátriai betegek fényképei szerepelnek (SzONDI, 1972). Amikor Szondi hozzáfogott a fényképek kereséséhez, nagy gondot fordított arra, hogy „tiszta típusok” kerüljenek kiválasztásra: csak azokat a fényképeket használta fel, ahol az ábrázolt személy diagnózisával kapcsolatban nem merültek fel kétségek, ismerte a páciens teljes kórtörténetét, mindezt kiegészítette a klinikai kezelés részletes leírásával, amellyel a betegség diagnózisa alátámasztható volt. A végsô soron kiválasztott fotók „tulajdonosainak” teljes családi genogramját is felvették. Könnyű belátni, hogy a szelekciós folyamatra áldozott erőfeszítés óriási volt, amelyben Szondit a kollégáiból álló csoport is segítette. A véglegesen kiválasztott fotók olyan személyeket ábrázoltak, akik Magyarországon, 
Svédországban, Ausztriában és Németországban éltek. Sajnos, több - ezen személyekról szóló - értékes információ elveszett, amikor Szondinak menekülnie kellett Budapestről (például az egyik stockholmi kriminológiai kórházból származó hat szadista élettörténete, de ehhez hasonlóan négy magyar személy - akiknek fotóját szintén felhasználták - családfája sem maradt fenn, ők korábban Szondi páciensei voltak Budapesten). Ezek között szerepel például a 7-es számú „h” kép, amely egy fiatal hermafroditát ábrázol, aki repülőgép-pilótaként szolgált a második világháború alatt. Mindezek ellenére ő pszichoszexuálisan nőnek érezte magát és később Szondi szakmai segítsége révén megváltoztatta a hivatalos születési regisztrációját és a nőiséget választotta, így engedélyezték számára a női ruhák viselését. Négy hermafrodita („h”) fényképét Magnus Hirschfeld híres munkájából vett át, ő a hajdani berlini rendőrség pszichiátere és szexológusa volt (ő volt egyben a szadisták és mazochisták világhírű múzeumának megalapítója is). A Szondi-teszt 48 fotójából 30-at Weygandt gyưjjtött össze. A ma már szokatlan képanyag magyarázata az, hogy a pszichiátria fejlődésének kezdeti szakaszában a tudomány irodalma teljesen „képi” volt. Ezek az atlaszok különböző pszichiátriai megbetegedésben szenvedổ személyek portréjait tartalmazták, rövid leírásokkal. E leírás rendszerint néhány feltűnő arcbeli vagy testi jellemzőt emelt ki, például „korpulens”, „lusta tolvaj”, „fanatikus paranoiás, hóhér fülekkel”, „demens, vészjósló arckifejezéssel” stb. A századfordulóra a pszichiátria felszabadult a leíró állapotból, de addig ez a fiatal tudomány a pszichodinamika felvázolásán túl nem tudott többet elérni: Weygandt képviselte a deskriptív pszichiátria csúcsát.

„Ezidáig senki sem tudta felülmúlni a különböző pszichiátriai entitások klasszikus leírásaiban, a benyomások tisztaságában, a részletek aprólékosságában, a viselkedések árnyalataiban és koherens előadásaiban. A pszichiátriai betegek Weygandt általi jellemzése felveszi a versenyt Shakespeare vagy Stevenson irodalmi jellemábrázolásával. Személyrajzait még ma is örömmel és haszonnal olvashatjuk. Ez az oka annak, hogy Szondi oly sok fotót választott Weygandt munkáiból. Figyelembe kell venni azt is, hogy Szondi a rendelkezésre álló 4000 képből választotta ki azt a 48 fotót, amelyet a teszt tartalmaz. Ezzel egyidejűleg arra is választ kaphatunk, hogy sok, szintén 48 képből álló, válogatás nélküli sorozat miért nem válhatott párhuzamos sorozattá, mint ahogy azt néhány amerikai kutató tévesen hitte" (SZONDI, MOSER, WEBB, 1959, 9.).

A fényképek érvényességének próbája a klinikai validitás volt. Különböző országokban - beleértve Angliát, Japánt és az Egyesült Államokat - a kutatók a Szonditeszt sorozataihoz hasonló módon kialakított sorozatokat fejlesztettek ki. Néhány esetben ezen sorozatokat kiértékelés céljából elküldték Szondinak. Szondi minden esetben látszólagos hasonlóságot talált: a párhuzamos sorozatok érvénytelenek voltak vagy a normál, vagy a klinikai csoport szempontjából. Az érvénytelenség okát nem nehéz felismerni.

A Szondi-teszt képeinek vizuális jellemzőit vizsgáló beszámoló alig olvasható, amelynek egyik lehetséges oka a teszt diagnosztikus célokhoz való szinte kizárólagos kötöttsége, $\mathrm{s}$ - meglehet - a képek igen gyenge fotótechnikai kivitele. 
SZAKÁCS és MÜNNICH (1972) vizsgálatának alapkérdése a szimpátia-antipátia támpontjai voltak. A Szondi-képeket az Identikit sémája szerint részekre bontották (homlok, szemöldök, szem, orr, száj, áll stb.), majd a legpreferáltabb részletekből összeállítottak egy elvi szimpátiamodellt, értelmiségi és alkoholista csoportoknál. Az értelmiségi csoport szimpátiaideálja a 3d, alkoholistáké az 5h kép volt. A preferált arcrészletek sorrendje (3 képnél összevonva) értelmiségi csoportnál: szem $\rightarrow$ száj $\rightarrow$ fül $\rightarrow$ orr stb.; alkoholistáknál: nyak/fül $\rightarrow$ homlok $\rightarrow$ áll $\rightarrow$ száj stb. Az értelmiségi csoportnál az elutasítás kiemelt régiója az áll; alkoholistáknál a szem. A szerzők szerint a képek objektíve különböznek a láthatóság mértékében (világosság, élesség stb.), a fejek pozíciójában, civilizációs jegyekben (például ápoltság), életkorban, nemre utaló és mimikai jegyekben, végül a tartozékok területén (például szemüveg).

FISCHER és KOCH (1985) kísérletet tettek a képek különböző kategóriák mentén történő értékelésére az alábbiak szerint:

1. részletesség (pontozása $1-5$-ig);

2. kontraszt (pontozása 1-6-ig, érdekes tapasztalatuk volt, hogy az $s$ képek sokkal kontrasztosabbak, mint a $h$ képek !);

3. élesség (pontozása 1-6-ig, az s képekről itt is megállapítják, hogy sokkal élesebbek, mint a $h$ képek!);

4. raszter (a képpontok finomságának mutatója, pontozása 1-5-ig, ahol 1 az eredeti fényképminóséget, 5 a látható képpontos, eleve raszteres, képek másolata);

5. megvilágítás (pontozása 1: szemből megvilágítva, nincs árnyék - 4: nagy árnyékrészletek, amelyek nem segítik az arcfelismerést [független az 1. ponttól]).

Továbbá:

6. kor (férfi-nő, alcsoportok 1: 25 évnél fiatalabb - 4: idősebb, mint 55 év);

7. ruházat (pontozása 1: teljes ruházat [például nyakkendő, ékszer] - 5: meztelen felsőtest;

8. tekintet (pontozása 1: kamerába néz - 7: behunyt vagy nem látható szemek;

9. nem (férfi - 1, nö - 2);

10. mimika (A FACS alapján kódolva).

Eredményeik szerint 1 . az élesség, megvilágítás és a részletesség befolyásolja a választások gyakoriságát; 2 . a raszter és a tekintet hasznos indikátor a faktorok és vektorok megkülönböztetésére. Összegezve azonban megállapítják, hogy ezek a hatások a választási gyakoriságot „enyhén befolyásolják”.

\section{A VIZSGÁLAT}

A Szondi-képek mindmáig feltáratlan módon „közvetítenek” ösztön eredetü feszültségeket, amelyekre a vizsgált személyek igen gyors szimpátia-antipátia válaszszal reagálnak. FISCHER és KOCH (1985) ismertetett vizsgálata jobbára az egyes képek leírására szorítkozott, így például „visszafogott mosoly, tiszta, világos tekintet, 
kiugró arccsont" stb. Ugyanebben a vizsgálatban az $s$ faktor képei kontrasztosabbnak tüntek, mint a $h$ faktor képei (!) - míg egy kép fénygrádiens-eloszlása és az általa hordozott ösztönfeszültség közötti összefüggés keresése nem tűnik megalapozottnak. Fischer és KOCH (1985) a vizsgálat további részében megadják az ún. átlagprofilt („kollektív favoritok”), amelyben 1839 profilból választották ki a leggyakrabban - 0,01-es szignifikanciaszinten - szimpatikusnak, illetve antipatikusnak választott képet (lásd 1. táblázat). Vizsgálatunk anyagát ezek a képek képezik.

A vizsgálat célja az arc vonzerómutatóinak, így az arc egyes régióinak, illetve metrikus adatainak vizsgálata. Hipotézisünk szerint - ha az átlagprofil „extrém módon” jeleníti meg a szimpatikusság/antipatikusság hátterében működő valamennyi pszichológiai mechanizmust, akkor - a csoportok képei között különbséget kapunk a fenti szempontok szerint.

1. táblázat. A Szondi-teszt képeinek átlagprofilja (Forrás: FiscHer és KoCH, 1985, 71.)

\begin{tabular}{|l|c|c|c|c|c|c|c|c|}
\cline { 2 - 9 } \multicolumn{1}{c|}{} & $\mathrm{h}$ & $\mathrm{s}$ & $\mathrm{e}$ & $\mathrm{hy}$ & $\mathrm{k}$ & $\mathrm{p}$ & $\mathrm{d}$ & $\mathrm{m}$ \\
\hline szimpatikus & 5,6 & 3,4 & 1 & - & - & 4 & - & $1,2,3$ \\
\hline antipatikus & 1 & 1,6 & 5 & 2,3 & 1,3 & 6 & 4 & 4 \\
\hline
\end{tabular}

\section{ELJÁRÁS}

A képeket beszkenneltük, tízszeresre nagyítottuk, hogy az arc egyes régióinak pontos határait (lásd alább) kijelölhessük. Az egyes régiók kijelölésében GRAMMER és THORNHILl (1994), valamint JOHNSTON és FRANKLiN (1993) munkáit vettük alapul (lásd 5. ábra):

1. d1: a szemek külső zugának távolsága $(\mathrm{mm})$;

2. d2:a szemek belső zugának távolsága $(\mathrm{mm})$;

3. d3: a pofacsontok távolsága (az arc szélessége a pofacsontok magasságában $(\mathrm{mm})$;

4. $\mathrm{d} 4$ : az orrtő szélessége $(\mathrm{mm})$;

5. d5 a száj szélessége $(\mathrm{mm})$;

6. fl: az arc hosszúsága (állcsúcs-homlokvonal távolsága (mm);

7. f2: a szemek középvonalának és a homlokvonalnak a távolsága $(\mathrm{mm})$;

8. f3: a szemek középvonalának (orrgyök) és az orrtőnek a távolsága $(\mathrm{mm})$;

9. f4: a száj középvonalának és az állcsúcsnak a távolsága $(\mathrm{mm})$.

10. x (=f1): a fej hossza, y: a szemek középvonala-állcsúcs távolság, z (=f2)

A képek beállítása miatt (például profil) vagy a szemek kijelölésének lehetetlensége, továbbá nagyítás okozta további minőségromlás miatt a képek PC-alapú feldolgozása bizonytalanná vált. Ezért a PTE Művészeti Karának felső éves grafikus hallgatóiból háromfős csoportot alakítottunk (2 férfi 1 nő), hogy művészeti anatómiai ismereteik birtokában, instrukcióinknak megfelelően a méréshez szükséges 
vonalakat jelöljék be. A csoport tagjai előzetesen nem ismerték a képanyagot, s azok forrása végig ismeretlen maradt számukra. A további feldolgozásra használt képek a következőek voltak: szimpatikus: h5, h6, s3, s4, m1, m2, m3; antipatikus: h1, s1, s6, e6, hy2, hy3, k1, k3, p6, d4, összesen 17 kép (kimaradt e1, m4.)

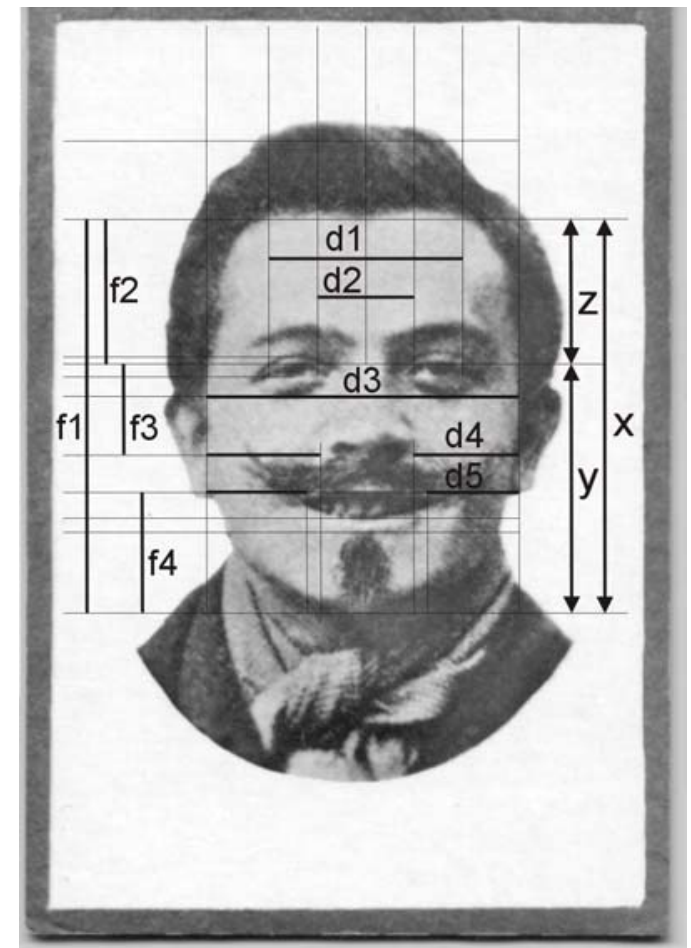

5. ábra. Egy Szondi-kép metrikus adatai

A mért adatok elemzése:

1. Mivel a kiinduló képnagyság eltérő volt - tehát a metrikus adatok nem voltak egybevethetőek -, ezért arányszámokat használtunk: d2/d3, d1/d3, d4/d3, d4/d5, d5/d3, f2/f1, f3/f1, f4/f1, f2/f3 + f4.

2. Az arc egyes régiói távolságának metrikus ( $\mathrm{mm})$ adataiból vizsgáltuk az egyes arcok megfelelését az aranymetszés szabályának $(\mathrm{x} / \mathrm{y}=\mathrm{y} / \mathrm{z})$.

\section{EREDMÉNYEK}

A kilenc arányszám adataiból tendenciaszerű különbséget kaptunk az alábbi arányok esetében: 
I. 1. $\mathrm{d} 4 / \mathrm{d} 3, \mathrm{t}=1,89(15), \mathrm{p}<0,07$, az antipatikus csoportban az orr szélesebb az arcszélességhez képest;

2. $\mathrm{f3} / \mathrm{f} 1, \mathrm{t}=1,96(15), \mathrm{p}<0,06$, az antipatikus csoportban az orr hosszabb a teljes archosszhoz képest;

3. d3/f1, t $=1,78(15), p<0,09$, az antipatikus csoportban az arc szélesebb az egész archosszhoz képest

4. f2/f1, $\mathrm{t}=1,73(15), \mathrm{p}<0,1$, a szimpatikus csoportban magasabb a homlok a teljes archosszhoz képest;

II. az arc arányossága: a szimpatikus csoport képei nem különböznek szignifikánsan az aranymetszés szabályától $(\mathrm{t}=0,29(6) \mathrm{p}<0,7)$; az antipatikus csoportnál ez az eltérés erősen szignifikáns $(t=3,42(9), p<0,008)$.

III. A diszkriminancia-analízis eredményei szerint a szimpatikus és az antipatikus csoportot legjobban az aranymetszés szabályainak való megfelelés mértéke és a d4/d3 arány választja el egymástól.

IV. Az összes arányra elvégzett clusteranalízis egy nagyobb antipatikus csoportot $(1 \mathrm{k}, 6 \mathrm{p}, 2 \mathrm{hy}, 6 \mathrm{~s}, 4 \mathrm{~d}, 3 \mathrm{k}, 1 \mathrm{~h})$, egy viszonylag nagy szimpatikus csoportot $(6 \mathrm{~h}, 3 \mathrm{~s}, 3 \mathrm{~m})$ és egy vegyes csoportot $(1 \mathrm{~m}, 5 \mathrm{~h}, 5 \mathrm{e}, 4 \mathrm{~s}, 2 \mathrm{~m}, 1 \mathrm{~s})$ eredményezett, amelyek - mint láthatjuk - a Szondi-faktoroktól függetlenek.

\section{MEGBESZÉLÉS}

A Szondi-teszt képanyagában a pszichiátriai betegségekben szenvedô személyekről készült fényképeket a „génikus kapcsolat” alapján választották ki. A sorsanalitikus elmélet szerint a vizsgálati személy saját génikus hajlamai mentén választ a fényképek sorozatából, a fotón megjelenített személy „közvetítésével”. Ez azt jelenti, hogy az adott személy ösztöntörekvéseit a valamilyen pszichiátriai megbetegedésben szenvedő személyt ábrázoló fénykép választásán keresztül ismerhetjük meg, mely választást a családi tudattalan irányít. Egy manifeszt vagy latens epilepsziást például pozitívan vagy negatívan fog befolyásolni a Szondi-teszt epilepsziást ábrázoló fényképe, a választás pedig a személy aktuális epileptoid fázisának megfelelôen alakul. A Szondi-teszt akár helyes, akár helytelen, a „választás nyelvére” alkalmazott fényképek kiállták a klinikai validitás próbáját.

Jelen beszámolónk arra tett kísérletet, hogy a kísérleti pszichológia nyelvére próbálja meg „lefordítani” a választás ösztöndeterminált folyamatát: feltárni azokat a metrikus adatokat, az arc régióinak arányait, amelyek a véletlent meghaladó módon szerepet kaphatnak abban, hogy egy arcot szimpatikusnak vagy éppen antipatikusnak tartunk.

Eredményeink szerint az átlagprofil két csoportjának képei néhány mérhető szempontban tendenciaszerűen különböznek egymástól, ez egybeesik az arc-vonzerő evolúciós pszichológiai irodalmának ,az átlagos arc vonzóbb, mint az attól bármely irányban eltérő arányú arcforma” módon megfogalmazott tételével (1., 2., 
3.); tendenciaszerü az az eredmény (4.) is, amely szerint a magas homlok a vonzerő egyik forrása (ez BRUNSWIK, 1956 vizsgálatában is igazolódott). A vonzó arc aranymetszésnek megfelelő szabályában kapott szignifikáns különbség a két csoport között, valamint a diszkriminancia-analízis igazolni látszik azt, hogy a metrikus adatokkal végzett elemzés alkalmas lehet a Szondi-képek vizsgálatára is. Fontos észrevennünk azonban azt is, hogy az aranymetszés szabályainak való megfelelés/meg nem felelés és a clusteranalízis eredményei függetlenek a Szondi-faktoroktól, így természetesen tisztában vagyunk azzal, hogy jelen beszámolónk kis lépést jelent abban a törekvésben, amely e két megközelítés között legalább kapcsolatot vél felfedezni.

\section{IRODALOM}

Alley, T. R. (1988) Physiognomy and Social Perception. In Alley, T. R. (ed.) Social and applied aspects of perceiving faces. 167-186. Erlbaum, Hillsdale

Alley, T. R., Cunningham, M. R. (1991) Averaged faces are attractive, but very attractive faces are not average. Psychological Science, 2, 123-125.

Allison, T., Ginter, H., McCarthy, G., Nobre, A. A., Puce, A., Luby, M., Spencer, D. D. (1994) Face recognition in human extrastriate cortex. Journal of Neurophysiology, 71, $821-825$.

BERECZKE I T. (1999) Szimmetria, párválasztás, szaporodás - új perspektívák az evolúciós pszichológiában. In Balogh T., Gévai G. (szerk.) Szimmetria, aszimmetria. II. 49-66. József Attila Tudományegyetem, Szeged

Bruce, V., Young, A. (1986) Understanding face recognition. British Journal of Psychology, $77,305-327$

Bruce, V., Young, A. (1998) In the eye of the beholder: The science of of face perception. Oxford University Press, Oxford

Brunelli, R., Poggio, T. (1993) Face Recognition: Features versus Templates. Pattern Analysis and Machine Intelligence Group, 15, 10., 1042-1052.

Brunswik, E. (1956) Perception and the representative design of psychological experiments. University of California Press, Berkeley

Costen, N. P., Parker, D. M., Craw, I. G. (1994) Spatial content and spatial quantisation effects in face recognition. Perception, 23, 129-146.

Costen, N. P., Parker, D. M., Craw, I. G. (1996) Effects of high-pass and low pass filtering on face identification. Perception and Psychophysics, 58, 602-612.

Cunningham, M. R., Roberts, A. R., Barbee, A. P., Druen, P. B. (1995) „The Ideas Of Beauty Are, On The Whole, The Same As OURS": Consistency And Variability In The Cross-Cultural Perception Of Female Attractiveness. Journal of Personality and Social Psychology, 68, 261-279.

DARw In, CH. (1892/1963) Az ember és az állat érzelmeinek kifejezése. Gondolat Könyvkiadó, Budapest

Eysenck, M. W., KeAne, M. T. (1997) Kognitív pszichológia. Nemzeti Könyvkiadó, Budapest

Fischer, M., KOCH, B. (1985) Szonditest. Portraits und Alltagsmensch. Eine Untersuchung der Bilder und des Bildwahlverhalten. Szondiana, 5, 63-108. 
Galton, F. (1883) Enquiries into Human Faculty and its Development. J. M. Dent., London

GORDOn, I. E. (1989) Theories of visual perception. Chapter 4.: Brunswik's probabilistic functionalism, 76-92. Wiley, New York

Grammer, K., Thornhill, R. (1994) Human facial attractiveness and sexual selection: the role of averageness and symmetry. Journal of Comparative Psychology, 108, 233-242.

HAIG, N. D. (1986) Investigating face recognition with an image processing computer. In Ellis, H. D., Jeeves, M. A., Newcombe, F., Young, A. (eds) Aspects of face processing. 85113. Dodrecht, Nijhoff

Johnston, V. S., Franklin, M. (1993) Is beauty in the eye of the beholder? Ethology and Sociobiology, 14, 183-199.

Klatzky, R. L., Martin, G. L., KAnE, R. A. (1982) Semantic interpretation effects on memory for faces. Memory and Cognition, 10, 195-206.

KovÁcS I. (1991) Egy tudományos vízió. David Marr: Vision... Pszichológia, 11, 77-125.

Kowner, R. (1996) Facial asymmetry and attractiveness judgment in developmental perspective. Journal of Experimental Psychology: Human Perception and Performance, 22, 662675.

Langlois, J. H., Ritter, J. M., Roggman, L. A., Vaughn, L. S. (1991) Facial diversity and infant preferences for attractive faces. Developmental Psychology, 27, 79-84.

Langlois, J. H., Roggman, L. A. (1990) Attractive faces are only average. Psychological Science, 1, 115-121.

Langlois, J. H., Roggman, L. A., Musselman, L. (1994) What is average and what is not average about attractive faces? Psychological Science, 5, 214-220.

MARR, D. (1982). Vision. Freeman, San Francisco

Moscovitch, M., Winocur, G. (1997) What is special about face recognition? Nineteen experiments on a person with object agnosia and dyslexia but normal face recognition. Journal of Cognitive Neuroscience, 9, 555-603.

Penton-Voak, I., Perrett, D. (2000) Consistency and individual differences in facial attractiveness judgements: an evolutionary perspective. Social Research, 67, 219-245.

RHODES, G. (1988) Looking at faces: First order and second order features as determinants of facial appearance. Perception, 17, 43-63.

Shepherd, J. W. (1981) Social factors in face recognition. In Davies, G., Ellis, H., Shepherd, J. (eds) Perceiving and Remembering Faces. 105-131. Academic Press, New York

Shepherd, J. (1989) The face and social attribution. In Young, A. W., Ellis, H. D. (eds) Handbook of Research on Face Processing. 289-320. Elsevier, North Holland

SHEPHERD, J. W., Ellis, H. D. (1996) Face recall - methods and problems. In Sporer, R., Malpass, G. K. (eds) Psychological issues in eyewitness identification. 125-148. Erlbaum, Mahwah

Slater, A., Schulenberg, C., Brown, E., Badenoch, M., Butterworth, G., Parsons, S., SAmuels, C. (1991) Newborn babies prefer attractive faces. Infant Behavior and Development, 21, 345-354.

Swaddle, J. P., Cuthill, I. C. (1995) Asymmetry and facial attractiveness: Symmetry may not be always beautiful. Proceedings of the Royal Society of London, 261, 111-116.

SzAKÁcs F., Münnich I. (1972) Szimpátia-modellek kutatása Szondi-képekkel. In Lénárd F. (szerk.) Környezet és tevékenység. Pszichológiai tanulmányok XIII. 575-593. Akadémiai Kiadó, Budapest 
SzOnd, L. (1972) Lehrbuch der experimentellen Triebdiagnostik. Hans Huber Verlag, BerlinStuttgart-Wien

Szondi, L., Moser, U., Webв, M. W. (1959) The Szondi Test. J. B. Lippincott Company, Philadelphia-Montreal

Tranel, D., Damasio, A. R., Damasio, H. (1988) Intact recognition of facial expression, gender and age in patients with impaired recognition of face identity. Neurology, 38, 690-696.

YIN, R. K. (1969) Looking at upside-down faces. Journal of Experimental Psychology, 81, 141145.

\title{
FACE RECOGNITION: THE POSSIBLE FEATURES OF SYMPATHY/ANTIPATHY ON SZONDI'S PICTURES
}

\author{
RÉVÉSZ, GYÖRGY-JÁRAI, RÓBERT
}

Examination of human faces' physical appearance to reveal the possible connections between characteristic features of faces and psychological character - is in the centre of interest in anthropology, ethnography, in forming literary characters since the time before psychology as science up to know.

However results of physiognomical researches proved to be attributions which are based on lineaments of face and feature of face-patterns. Those examinations are statistically unstable whose aim was to reveal teh connections between feature of faces and characteristics shown on photographes.

Recently in the field of physical attractive forcea lot of ethological, sociobiological examinations' results were published about the connections of averageness, symmetry and attractivity.

We have very few dates about the examination of the Szondi test's pictures. There was found only tendency-like connection about what effects the visual characteristics of the pictures (exposure, contrast, clearness, details, raster, etc.) have on the choosing.

According to Szondi the most important factor in choosing pictures is the dynamics of instinct requirements, which seems to be based on to Lewinian appeal of the picture.

In our research we found some tendency-like differences in the rates of the Szondi-pictures' metrical datas and we found significal differences according to the rules of golden section between likeable and antipathetic groups of average profile.

Key words: models of face recognition, feature detection ws. template matching, face and character, averageness, symmetry, attractivity, the ,proportionality” of face 